\title{
Grepafloxacin clinical program for lower respiratory infections
}

\author{
Arne C Rodloff MD
}

\begin{abstract}
AC Rodloff. Grepafloxacin clinical program for lower respiratory tract infections. Can J Infect Dis 1998;9(Suppl E):23E-26E.
\end{abstract}

The present paper evaluates the clinical trial program in lower respiratory tract infections treated with a new fluoroquinolone antibiotic, grepafloxacin. Unlike older quinolones, grepafloxacin has excellent activity against Gram-positive organisms, which include Streptococcus pneumoniae and 'atypical' pathogens Legionella species, Mycoplasma pneumoniae and Chlamydia pneumoniae. Grepafloxacin has a long half-life of 12 to $15 \mathrm{~h}$, which allows once daily dosing. Six studies have been conducted regarding community-acquired lower respiratory tract infections (LRTIs), four about community-acquired pneumonia (CAP) and two about acute bacterial exacerbations of chronic bronchitis $(A B E C B)$. In these studies, grepafloxacin demonstrated clinical equivalence with standard therapies, but, in patients with documented infections, grepafloxacin was statistically superior to amoxycillin in both $\mathrm{CAP}$ and $\mathrm{ABECB}$. The new fluoroquinolone has a good safety profile, comparable with that of ciprofloxacin. The most common adverse effects of grepafloxacin were nausea and a metallic taste; however, these effects resulted in only a few discontinuations of therapy. With the increasing prevalence of resistance in pathogens isolated from community-acquired LRTIs, grepafloxacin offers a good alternative for monotherapy in these patients.

Key Words: Bronchitis, Grepafloxacin, Pneumonia

\section{Programme d'essais cliniques sur la grépafloxacine pour les infections des voies respiratoires inférieures}

RÉSUMÉ : Le présent article évalue le programme d'essais cliniques sur les infections des voies respiratoires inférieures traitées avec un nouvel antibiotique de la famille des fluoroquinolones, la grépafloxacine. À l'inverse des quinolones plus anciennes, la grépafloxacine a démontré une activité bactéricide excellente contre les micro-organismes grampositifs comprenant Streptococcus pneumoniae et les pathogènes " atypiques » de l'espèce de Legionella, Mycoplasma pneumoniae et Chlamydia pneumoniae. La grépafloxacine a une longue demi-vie de 12 à $15 \mathrm{~h}$, ce qui permet de l'administrer selon une posologie uniquotidienne. Six études ont été menées sur les infections des voies respiratoires inférieures extra-hospitalières (IVRI), quatre sur la pneumonie extra-hospitalière (PEH) et deux sur les exacerbations bactériennes aiguës de la bronchite chronique (EBABC). Dans ces études, la grépafloxacine a prouvé qu'elle était cliniquement équivalente à d'autres traitements standards, mais chez les patients dont les infections avaient été documentées, la grépafloxacine s'est révélée statistiquement supérieure à l'amoxicilline à la fois pour la PEH et pour les EBABC. La nouvelle fluoroquinolone a un bon profil d'innocuité comparable à celui de la ciprofloxacine. Les effets indésirables les plus courants de la grépafloxacine sont les nausées et un goût métallique ; cependant, ces effets ont seulement entraîné quelques abandons du traitement. Étant donné l'augmentation de la prévalence de la résistance chez les pathogènes isolés dans les IVRI extra-hospitalières, la grépafloxacine constitue un bon choix de monothérapie pour ces patients.

Institut für Medizinische Mikrobiologie, und Infecktionsepidemiologie, der Universität Leipzig, Leipzig Germany

Correspondence and reprints: Dr Arne C Rodloff. Director, Institut für Medizinische Mikrobiologie und Infecktionsepidemiologie, der Universität Leipzig, Liebigstrasse 24, D-04103 Leipzig Germany. Telephone 0341-9715200, fax 0341-9715209 
$\mathrm{T}$ he management of community-acquired lower respiratory tract infections (LRTIS) usually involves the use of empirical therapy. In community-acquired pneumonia (CAP), in up to $60 \%$ of cases, the causative organism is not known (1). Therefore, initial treatment may need to cover all the major pathogens, both the typical bacteria and the 'atypical' pathogens.

Because of the increasing resistance of pneumococci to penicillin and macrolides, new alternatives for the treatment of these infections are being evaluated. Most quinolones are well absorbed from the gastrointestinal tract, penetrate at high levels into respiratory tissues, are rapidly bactericidal and have high activity against most Gram-negative organisms. However, until recently, quinolones have not been considered sufficiently active against the Streptococcus pneumoniae to be first-line therapy in the treatment of community-acquired LRTIS.

Grepafloxacin has significantly increased activity against Gram-positive organisms compared with that of the older quinolones. Its minimal inhibitory concentration (MIC90) value for $S$ pneumoniae is $0.25 \mathrm{mg} / \mathrm{L}$ (2), even in highly penicillinresistant strains (3). At a dose of $400 \mathrm{mg}$ once daily, grepafloxacin levels in respiratory tissues exceed the $\mathrm{MIC}_{90}$ of $S$ pneumoniae strains within 40 mins of oral dosing (4).

As part of the grepafloxacin clinical study program for the registration of this new antimicrobial agent, nearly 3000 patients were entered into six phase III studies conducted in the United States, United Kingdom and Ireland. All studies were conducted in out-patient settings using oral medication. There were four studies for the treatment of CAP and two studies for the treatment of acute bacterial exacerbations of chronic bronchitis (ABECB).

\section{GREPAFLOXACIN IN CAP}

In the United States, there are four million cases of CAP each year. Of these, only 600,000 are hospitalized, with the majority being treated in an out-patient setting. The total cost

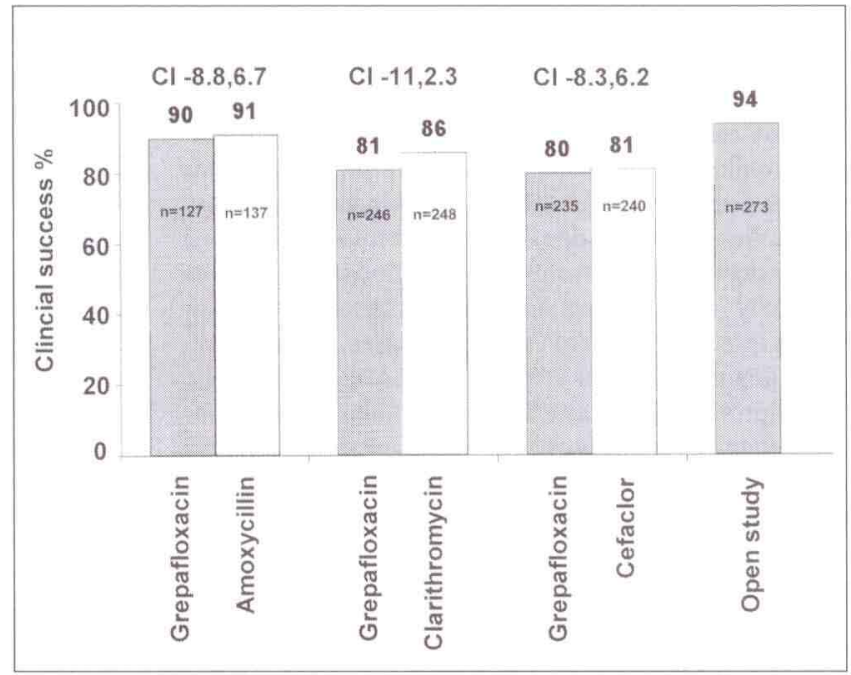

Figure 1) Grepafloxacin clinical studies in an intent-to-treat population - pneumonia clinical success rates at three to five days post-treatment. Ninety-five per cent confidence intervals (CIS) are given of treating CAP in the United States is estimated at four billion US dollars per year (5). Studies conducted in the United Kingdom show that the majority of this cost is due to hospitalization.

Four phase III studies were performed of CAP treated with grepafloxacin $600 \mathrm{mg}$ once daily. This dose of grepafloxacin was chosen to provide blood levels with approximately the $\mathrm{MIC}_{90}$ of $S$ pneumoniae for the entire $24 \mathrm{~h}$ dosing interval (6). Three of these studies were comparative (versus amoxycillin $500 \mathrm{mg}$ tid (7), clarithromycin $250 \mathrm{mg}$ bid and cefaclor $500 \mathrm{mg}$ tid), and one was a noncomparative, open study (8). The studies were performed between 1992 and 1993, when penicillin and macrolide resistance in $S$ pneumoniae was low (less than $2 \%)$ at the study sites.

Patients enrolled were all adults, with clinical signs and symptoms of pneumonia. The diagnosis was confirmed by a chest x-ray. For all patients, a pretreatment sputum culture was obtained, and, for patients in the open study, serology tests for Mycoplasma pneumoniae and Legionella pneumophila were obtained. Patients received post-treatment an x-ray at three to five days, and clinical and microbiological response was assessed at 28 to 42 days post-treatment.

As expected with an equivalence registration trial, clinical equivalence was demonstrated with the comparator treatment regimens at the end of treatment. The results are depicted in Figure 1 with 95\% confidence intervals (CIs) for differences.

The major pathogen isolated from patient's sputum specimens was $S$ pneumoniae as anticipated. Very few of these isolates had reduced susceptibility to penicillin. There were 127 patients with pneumococcal infections in the grepafloxacin group. Of these patients, 121 (95\%) had a successful outcome. Microbiological success rates of grepafloxacin were equivalent to those of clarithromycin and cefaclor at EOT but were statistically superior to that of amoxycillin in eradicating Haemophilus influenzae. $(\mathrm{P}=0.006)$. Overall, in the intent to treat population with proven infections (Figure 2) and in the microbiologically evaluable population, grepafloxacin was superior to amoxycillin (100\% versus $81 \%$; CI 95\% 6.7, 33.2).

In the open study, grepafloxacin was successful in the treatment of both $M$ pneumoniae and $L$ pneumophila infections, with clinical success rates of $98 \%$ (58 of 59) and $93 \%$ (13 of 14) respectively at EOT.

\section{GREPAFLOXACIN IN ABECB}

Two comparative phase III studies were performed with amoxycillin $500 \mathrm{mg}$ tid (9) and ciprofloxacin $500 \mathrm{mg}$ bid as comparators (10). In both studies, two doses of grepafloxacin were studied; $400 \mathrm{mg}$ once daily and $600 \mathrm{mg}$ once daily. More than 1200 patients were entered into the study. All patients were adults, had clinical signs and symptoms of ABECB, and had pneumonia excluded by a chest x-ray. Sputum specimens had less than 10 epithelial cells per low powered field and less than 25 leukocytes per low powered field in all patients before enrollment. These specimens were sent for culture, and patients were assessed post-treatment at three to five days and 14 to 28 days.

Clinical success rates were similar to those with the com- 


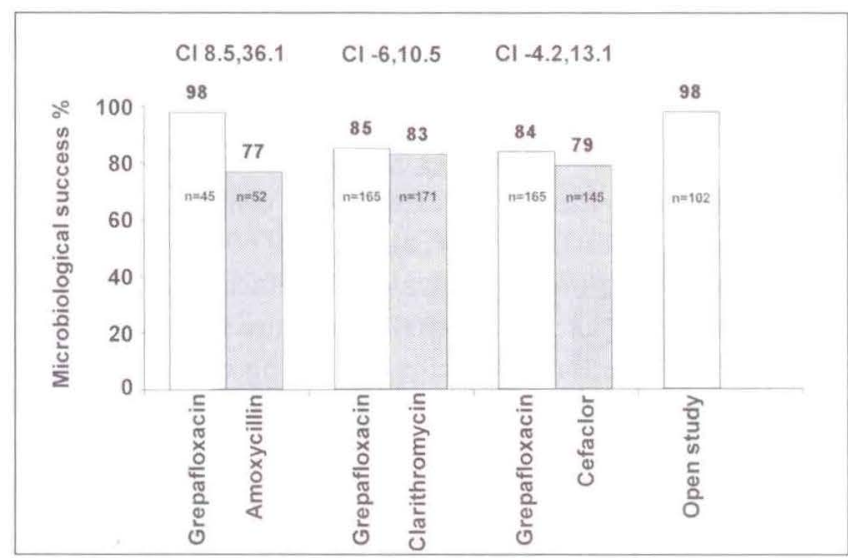

Figure 2) Grepafloxacin clinical studies in a microbiological intent to treat population (all pathogens) - pneumonia microbiological success rates at three to five days post-treatment. Ninety-five per cent confidence intervals (CIS) are given

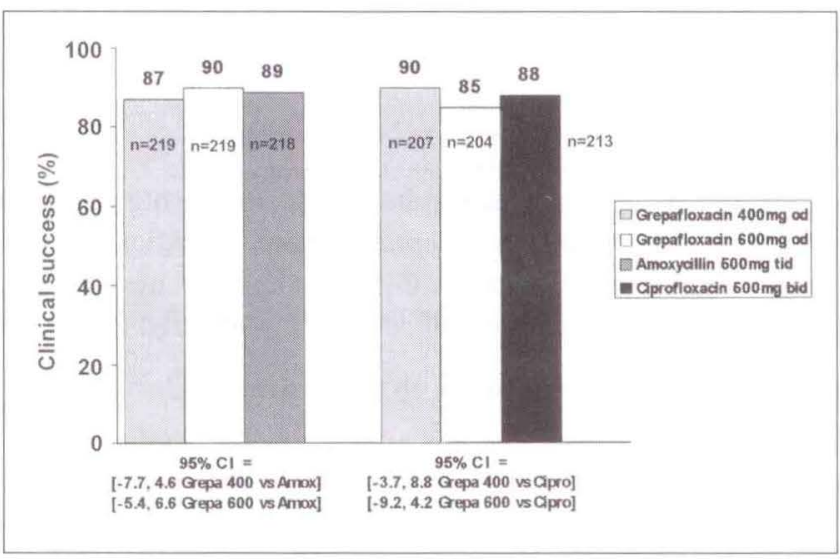

Figure 3) Grepafloxacin clinical studies in an intent-to-treat population - acute bacterial exacerbations of chronic bronchitis clinical success rates at three to five days post-treatment. Ninety-five per cent confidence intervals (CIS) are given

parator treatment regimens, and the two doses of grepafloxacin were equivalent (Figure 3).

Eradication rates achieved with grepafloxacin $400 \mathrm{mg}$ and $600 \mathrm{mg}$ per day were statistically superior to amoxycillin at EOT. Equivalence to ciprofloxacin was also demonstrated (Figure 4).

\section{SAFETY}

For the registration program of grepafloxacin, a total of 22 phase II/III studies were performed with more than 3000 patients exposed to the drug. Few patients were withdrawn from treatment due to adverse effects of grepafloxacin, approximately $2 \%$ with the $400 \mathrm{mg}$ dose, and $4 \%$ with the $600 \mathrm{mg}$ dose. A metallic taste and nausea were the major adverse events reported. The metallic taste is due to grepafloxacin secretion into the saliva. Most patients do not find this especially unpleasant, which is confirmed by the fact that less than $1 \%$ withdrew from treatment because of it. The major side effects are summarized in Table 1.

Gastrointestinal adverse reactions are a recognized side ef-

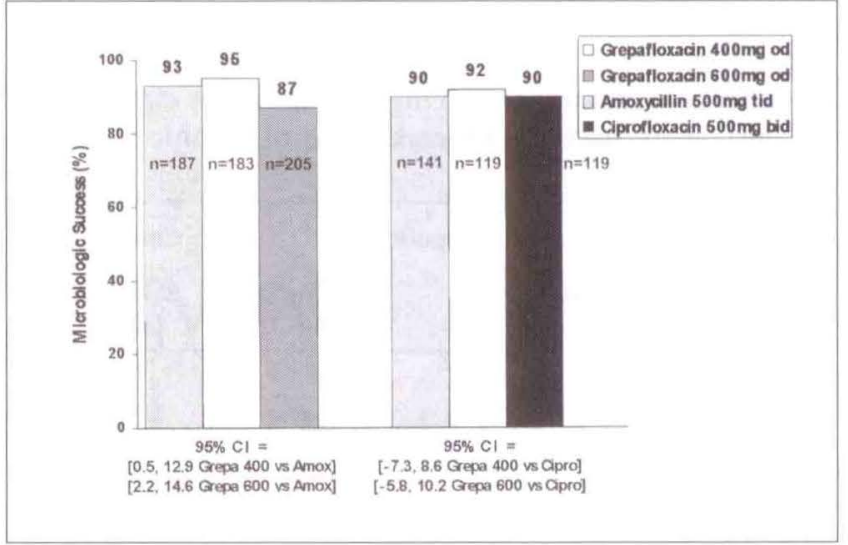

Figure 4) Grepafloxacin clinical studies in a microbiological intent to treat population (all pathogens) - microbiological success rates at three to five days post-treatment. Ninety-five per cent confidence intervals (CIS) are given

TABLE 1

Safety: Most common adverse effects of grepafloxacin (incidence of $5 \%$ or greater) observed in multiple dose studies

\begin{tabular}{lccc}
\hline & \multicolumn{3}{c}{ Grepafloxacin dose } \\
$\begin{array}{l}\text { Adverse effect } \\
\text { reported (\%) }\end{array}$ & $\begin{array}{c}\mathbf{4 0 0} \mathbf{~ m g} \\
(\mathbf{n = 1 0 6 9 )}\end{array}$ & $\begin{array}{c}\mathbf{6 0 0} \mathbf{~ m g} \\
(\mathbf{n = 1 4 0 6})\end{array}$ & $\begin{array}{c}\text { All controls } \\
(\mathbf{n}=\mathbf{1 5 7 9 )}\end{array}$ \\
\hline Nausea & 11.8 & 15.4 & 8.1 \\
Unpleasant taste & 9.0 & 16.8 & 1.6 \\
Headache & 7.5 & 8.1 & 8.9 \\
Vaginitis* & 5.1 & 1.4 & 5.4 \\
Dizziness & 5.0 & 6.3 & 2.9 \\
Vomiting & 2.2 & 7.6 & 3.7 \\
Diarrhea & 3.9 & 5.2 & 4.4 \\
Rhinitis & 3.1 & 5.9 & 3.8 \\
\hline
\end{tabular}

*Incidence is the percentage of females in the group who experienced the adverse event

fect of quinolone antibiotics. In Table 2, the adverse effects of grepafloxacin and ciprofloxacin are given for patients enrolled in the ABECB trials.

The incidence of nausea with grepafloxacin therapy was similar to that of ciprofloxacin. Unpleasant taste was reported significantly more often with grepafloxacin, but significantly more headache and rhinitis were noted with ciprofloxacin.

Photosensitivity reactions have occurred with some quinolones. In the grepafloxacin trials, patients were not given instructions to avoid sunlight exposure and were all treated as out-patients. This was appropriate because a previous study in healthy volunteers had shown that the photosensitising effect of grepafloxacin was equivalent to that of ciprofloxacin (11). The maximum effect seen with grepafloxacin was erythema. There were no second- or third-degree burns, and only three patients, receiving the $600 \mathrm{mg}$ dose, withdrew from treatment due to this undesirable event.

Prolongation of the QT interval corrected for heart rate (QTC) has been an increasingly recognized adverse effect associated with a number of compounds, including macrolide and 
TABLE 2

Comparison of the most common adverse effects for grepafloxacin $400 \mathrm{mg}$ or $\mathbf{6 0 0} \mathrm{mg}$ with those for ciprofloxacin $500 \mathrm{mg}$ (acute bacterial exacerbations of chronic bronchitis studies)

\begin{tabular}{|c|c|c|c|}
\hline \multirow[b]{2}{*}{$\begin{array}{l}\text { Adverse effect } \\
\text { reported (\%) }\end{array}$} & \multicolumn{2}{|c|}{ Grepafloxacin } & \multirow{2}{*}{$\begin{array}{l}\text { Ciprofloxacin } \\
\begin{array}{l}500 \mathrm{mg} \text { bid } \\
(\mathrm{n}=232) \%\end{array}\end{array}$} \\
\hline & $\begin{array}{c}400 \mathrm{mg} \text { od } \\
(n=483)\end{array}$ & $\begin{array}{c}600 \mathrm{mg} \text { od } \\
(\mathrm{n}=471)\end{array}$ & \\
\hline Nausea & 12.4 & 19.7 & 15.5 \\
\hline Unpleasant taste & $9.5^{*}$ & $16.3^{*}$ & 3.4 \\
\hline Headache & $11.0^{*}$ & $8.9^{*}$ & 19.4 \\
\hline Dizziness & 6.2 & 8.3 & 6.0 \\
\hline Rhinitis & 6.0 & $4.2^{*}$ & 8.2 \\
\hline Abdominal pain & 3.7 & 2.8 & 5.2 \\
\hline Pain & 3.3 & 3.2 & 5.2 \\
\hline Vomiting & 3.3 & 8.3 & 5.2 \\
\hline Dyspepsia & 3.3 & $5.9^{*}$ & 2.2 \\
\hline
\end{tabular}

${ }^{*} P<0.05$ for grepafloxacin versus ciprofloxacin; od Once daily

quinolone antibiotics. A recent study with erythromycin demonstrated a $31 \mathrm{~ms}$ increase in the QTC (12). In two phase I grepafloxacin studies, the QTc prolongation was equivalent to placebo arms. In a third study, involving 48 elderly subjects, a small average increase (less than $2 \mathrm{~ms}$ ) was observed. In the

\section{REFERENCES}

1. Meyer RD, Finch RG. Community-acquired pneumonia. J Hosp Infect 1992;22(Suppl A):51-4.

2. Fuchs PC, Barry AL, Brown SD. Tentative interpretive criteria for testing the susceptibility of Streptococcus pneumoniae to eight fluoroquinolones. Diagn Microbiol Infect Dis 1996;26:23-7.

3. Spangler SK, Jacobs MR, Pankuch GA, Appelbaum PC. Susceptibility of 170 penicillin-susceptible and penicillin-resistant pneumococci to six oral cephalosporins, four quinolones, deacetylcefotazime, Ro 23-9424 and RP 67829. J Antimicrob Chemother 1993:31:273-80.

4. Cook PJ, Andrews JM, Wise R, Honeybourne D, Moudgil H. Concentrations of OPC-17116, a new fluoroquinolone antibacterial, in serum and lung compartments. J Antimicrob Chemother 1995;35:317-26.

5. Medicare and Medicaid Statistical Supplement 1995. Health Care Finance Rev 1995;16.

6. Efthymiopoulos C. Pharmacokinetics of grepafloxacin. J Antimicrob Chemother 1997;4(Suppl A):35-43.

7. O'Doherty B, Dutcman DA, Pettit R, Maroli A. Randomized, double-blind, comparative study of grepafloxacin and amoxycillin in the treatment of patients with phase III program, no arrhythmias were noted despite many patients receiving proarrhythmic drugs concomitantly.

\section{CONCLUSIONS}

Grepafloxacin has been extensively evaluated in community-acquired LRTIs. In CAP, at a dose of $600 \mathrm{mg}$ once daily, grepafloxacin is clinically equivalent to cefaclor and clarithromycin, and superior to amoxycillin therapy in patients with documented infections. With the increasing resistance of the major pathogens to the older antimicrobial agents, grepafloxacin seems to be of value in these infections.

In $\mathrm{ABECB}$, the two doses of grepafloxacin were clinically equivalent to the comparator treatment regimens, and, in patients with documented infections, grepafloxacin was superior to amoxycillin. Because of the clinical equivalence of the two dose regimens of grepafloxacin, and the better side-effect profile of the lower dose, the $400 \mathrm{mg}$ dose is recommended in ABECB.

The safety profile has been well characterized and is comparable with that of ciprofloxacin. Notably, the potential for phototoxicity is low, and the QTC prolongation is smaller than with some other antibiotics.

In view of these clinical results and the increasing penicillin and macrolide resistance of $S$ pneumoniae, grepafloxacin 400 $\mathrm{mg}$ for $\mathrm{ABECB}$ and $600 \mathrm{mg}$ for CAP is an appropriate antibiotic in the out-patient treatment of community-acquired LRTIS. community-acquired pneumonia. J Antimicrob Chemother 1997;40(Suppl A):73-81.

8. Topkis S, Swarz H, Breisch SA, Maroli AN. Efficacy and safety of grepafloxacin $600 \mathrm{mg}$ daily for 10 days in patients with community-acquired pneumonia. Clin Ther 1997; 19:975-88

9. Langan CE, Granfield R, Breische S, Pettit R. Randomized, double-blind study of grepafloxacin versus amoxycillin in patients with acute bacterial exacerbations of chronic bronchitis. J Antimicrob Chemother 1997;40(Suppl A):63-72.

10. Chodosh S, Lakshminarayan S, Swarz H, Breisch S. Efficacy and safety of a 10-day course of 400 or 600 milligrams of grepafloxacin once daily for treatment of acute bacterial exacerbations of chronic bronchitis: comparison with a 10-day course of 500 milligrams of ciprofloxacin twice daily. J Antimicrob Chemother 1998;42:114-20.

11. Ferguson J, Dawe R. Phototoxicity in quinolones: comparison of ciprofloxacin and grepafloxacin. J Antimicrob Chemother 1997;40(Suppl A):93-8.

12. Freeman J, Platt R. Erythromycin prolongs the QTc interval among patients with pneumonia. Pharmacoepidemiol Drug Saf 1997;6:13-19. 


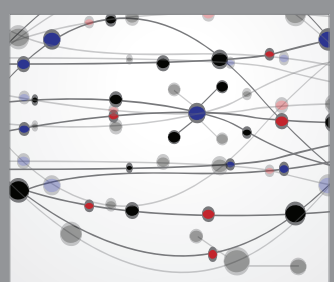

The Scientific World Journal
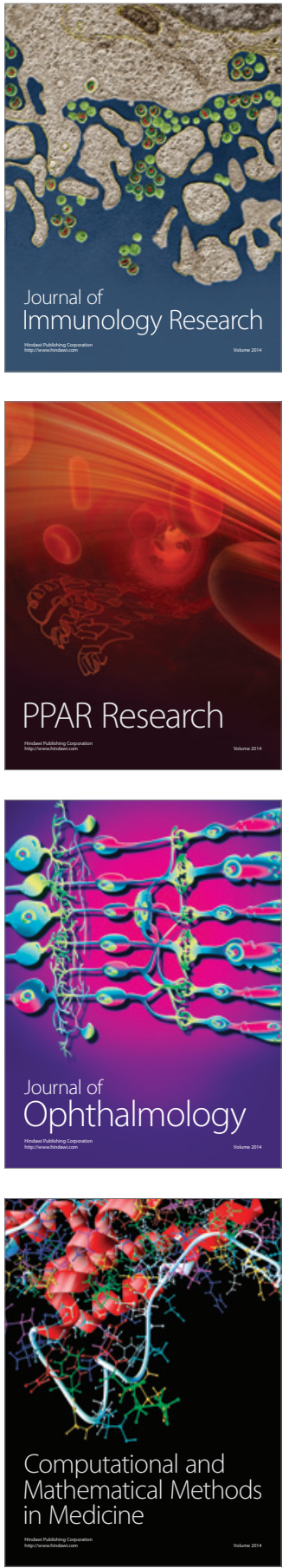

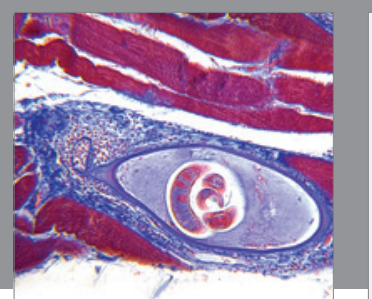

Gastroenterology Research and Practice

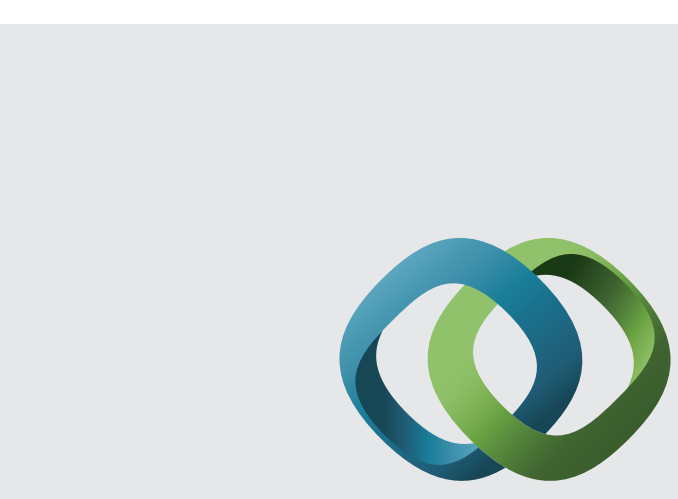

\section{Hindawi}

Submit your manuscripts at

http://www.hindawi.com
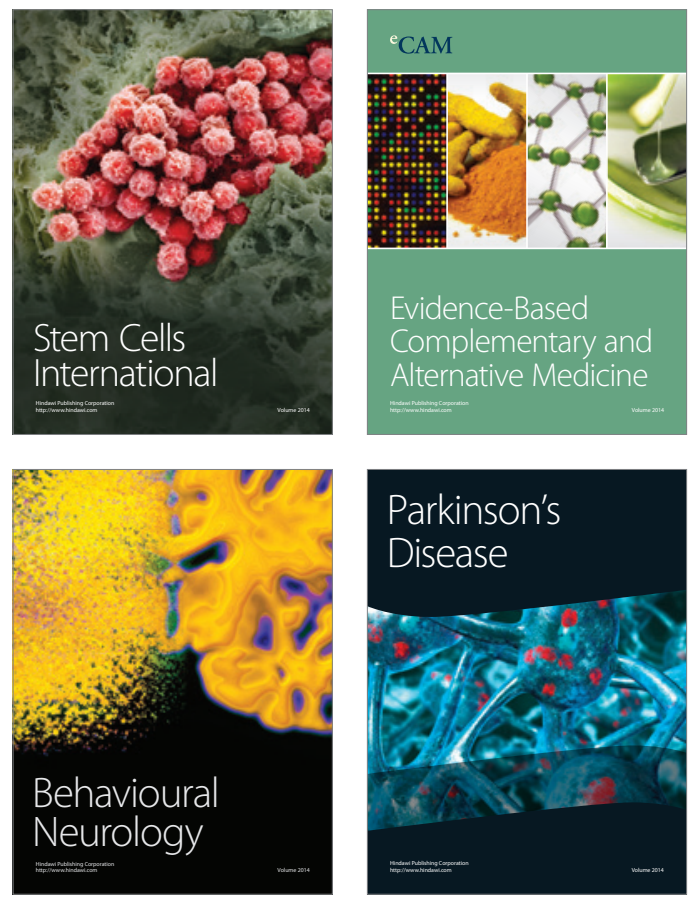
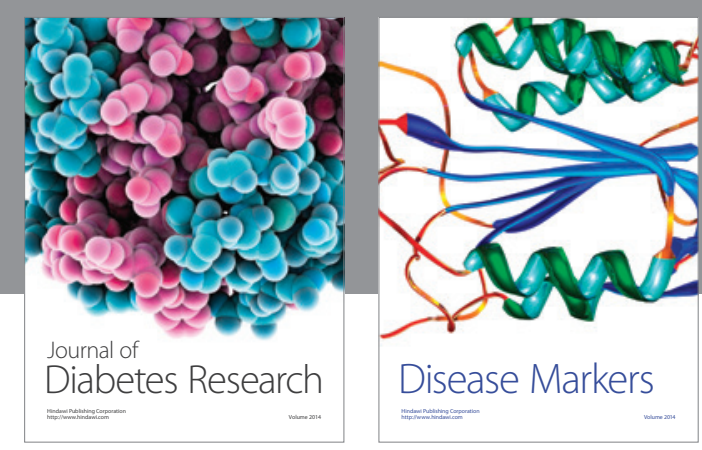

Disease Markers
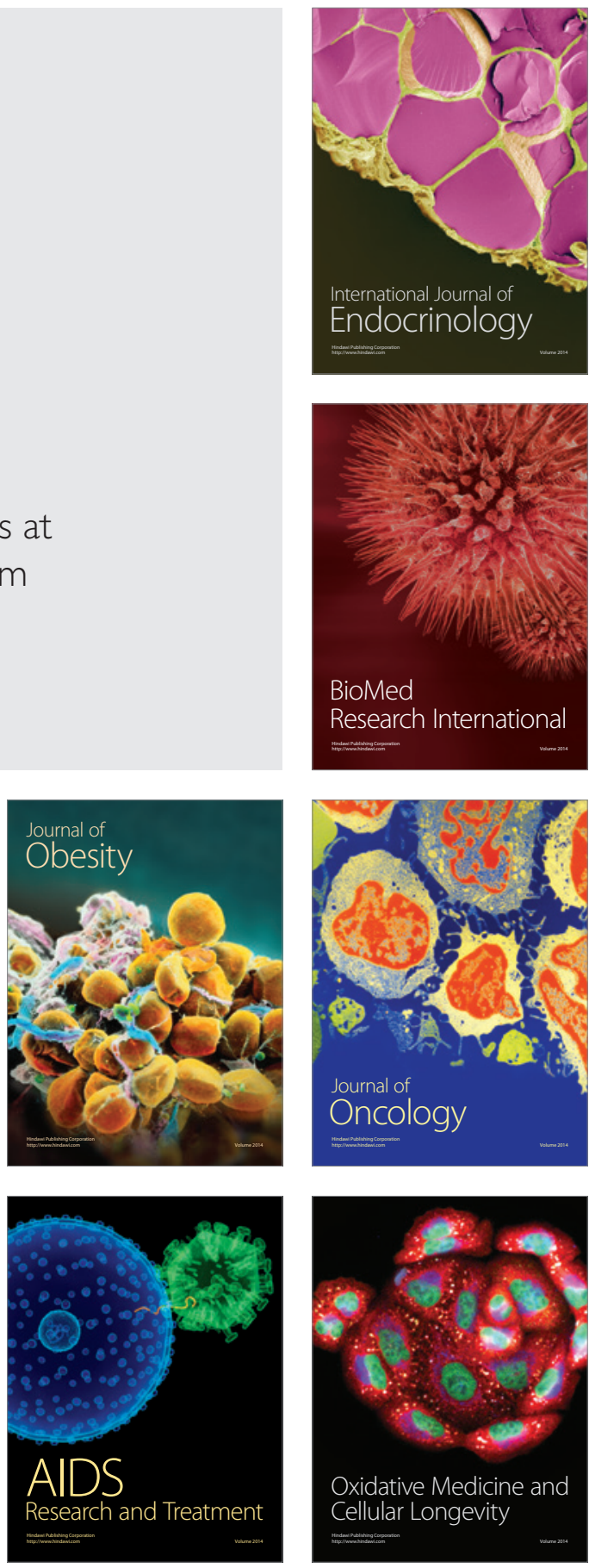